\title{
sciendo
}

10.2478/aucft-2021-0011

\section{EFFECT OF ALCALASE ON ANTIOXIDANT AND ANTIHYPERTENSIVE ACTIVITIES OF GOAT MILK FERMENTED BY LACTOBACILLUS PLANTARUM L60 AND LACTOBACILLUS RHAMNOSUS LR22}

\author{
- Research paper -
}

\author{
Guowei SHU*1, Zifei WANG*, Chunji DAI*, Chunxu YAO*, Xu Dong**, Hongchang WAN**, \\ $\mathrm{He} \mathrm{CHEN}^{*}$
*School of Food and Biological Engineering, Shaanxi University of Science \& Technology, Xi'an, 710021, China
**Shaanxi Yatai Dairy Co., Ltd., Xianyang, 713701, China

\begin{abstract}
Effect of alcalase addition, inoculum size, bacterial ratio, fermentation time and temperature on antioxidant and antihypertensive activities of goat milk fermented by Lactobacillus plantarum L60 and Lactobacillus rhamnosus LR22 was studied by using DPPH free radical scavenging rate, ACE inhibition rate, $\mathrm{pH}$, and titer acidity as responses through single factor experiments. The results showed that the optimal alcalase addition, inoculum size, bacterial ratio, fermentation time and temperature was $0.15 \%, 5 \%, 1: 1,12 \mathrm{~h}$ and $37^{\circ} \mathrm{C}$, respectively, the probiotic goat milk prepared under these conditions had high antioxidant and antihypertensive activities.
\end{abstract}

Keywords: goat milk; Alcalase;Lactobacillus plantarum Lactobacillus rhamnosus; antioxidant, ACE inhibition

\section{INTRODUCTION}

Probiotics have a wide range of health care effects, such as reducing lactose intolerance, lowering cholesterol levels, stimulating the immune system, alleviating constipation, increasing mineral absorption, antibacterial, anti-cancer, anti-oxidation, and relieving elevated blood pressure (Ribeiro et al., 2015). With the further improvement of people's living standards, people also pay more attention to their own health. Therefore, the anti-oxidation and alleviating blood pressure functions of probiotics have become more and more popular research topics.

Goat milk is praised for its high nourishment value, which is indispensable to human basic life activity. Goat milk is rich in protein, fatty acids and vitamins, so it is of great biological value. Compared with human milk and cow's milk, goat's milk has higher concentrations potassium, calcium and phosphorus; goat milk has a relatively higher protein content (Soares et al., 2013; Xu et al., 2015).

In addition, goat milk contains a variety of biologically active peptides with powerful antioxidant capacity (De et al., 2014).

Received: 14.02 .2021

Accepted in revised form: 30.05.2021
Milk-derived antioxidant peptide is a biological peptide that has been widely studied. Oxidative stress can cause many chronic diseases, such as tumors and age-related diseases (Kris et al., 2002). In normal physiological processes, the production of free radicals can cause cell damage and produce a variety of physiological changes (Tovar et al., 2017). The milk-derived antioxidant peptides can scavenge such free radicals, thereby protecting the human body from related diseases. Therefore, research on milk-derived antioxidant peptides has been rapidly developed in recent years.

At present, milk-derived antioxidant peptides are mainly prepared by enzymatic hydrolysis and fermentation methods (Liang et al., 2014). The preparation of antioxidant peptides by enzymatic hydrolysis is fast and convenient. The fermentation method relies on the fermentation of lactic acid bacteria to produce protease, and then prepares biologically active peptides through protease hydrolysis. Elfahri (Elfahri et al., 2016) used four bacterials of Lactobacillus helveticus ASCC953, ASCC474, ASCC1188 and ASCC1315 to ferment cow's milk at $37^{\circ} \mathrm{C}$ for 12 hours, and the fermented milk obtained has a higher DPPH free radical scavenging rate. Kudoh (Kudoh et al., 2001) used 
Lactobacillus delbrueckii to ferment dairy products and obtained fermented milk with high DPPH free radical scavenging ability. Soleymanzadeh et al, (2016) fermented cow milk and camel milk with lactic acid bacteria isolated from traditionally fermented camel milk, and found that the DPPH scavenging ability of fermented camel milk was significantly improved.

The milk-derived ACE inhibitory peptide in goat milk is another biological peptide that has been widely studied. Hypertension is considered to be the main cause of CHD (coronary heart disease) (Fitzgerald et al., 2004). The conversion of angiotensin I to angiotensin II (vasoconstrictor) is catalyzed by an Angiotensin-converting enzyme. It has been reported that using specific LAB or protease treated various milk media, then can obtain ACE-I peptides (Van der Ven et al., 2002; Meena et al., 2008). Seppo (Seppo et al., 2004) fermented milk with Lactobacillus helveticus LBK-16H. Fermented milk has an ACE inhibitory effect. Clinical trials show that fermented milk products rich in ACE inhibitory peptides have a certain effect on the regulation of blood pressure. Therefore, people began to pay more and more attention to the development of milk-derived ACE inhibitory peptides.

Milk-derived ACE inhibitory peptides are also mainly prepared by enzymatic hydrolysis and fermentation methods. At present, the proteases commonly used to prepare ACE inhibitor peptides include alkaline protease, trypsin, pepsin and Alcalases. Fermented milk prepared by fermentation also has high ACE inhibitory activity. Liang (Liang et al., 2009) determined that the best extraction process for manufacturing ACE inhibitory peptides from skim milk fermented by Lactobacillus helveticus. The ACE inhibition rate of the obtained fermentation product was $92.26 \%$. Lu (Lu et al., 2010) used Lactobacillus helveticus to ferment whey protein, and the ACE inhibition rate of the obtained fermentation product could reach $89.33 \%$. Nakamura (Nakamura et al., 1995) used lactic acid bacteria and yeast to ferment skim milk to purify ACE inhibitory peptides. The ACE inhibitory rate was $74.4 \%$, indicating that milkderived protein can provide the main raw material

\section{MATERIAL AND METHODS}

\section{Bacteria and probiotic activation}

L. plantarum L60 and L. rhamnosus LR22, isolated from fermented goat milk, was provided by the for preparing antioxidant peptides and ACE inhibitor peptides.

In recent years, research on goat milk has gradually increased at home and abroad. Shan Jing (Shan et al., 2009) studied the fermentation conditions of skimmed goat milk fermented by probiotics. In their research the maximum number of viable bacteria in fermented milk is $9.59 \times 10^{8} \mathrm{cfu} / \mathrm{mL}$, and the titer acidity reaches $198.56^{\circ} \mathrm{T}$. There are few reports on the preparation of goat milk powder with bioactive peptides of probiotics. There are few reports on the preparation of active peptides from goat milk produced by probiotic-assisted fermentation of goat milk.

In previous work, the effect of five proteases (Alcalase, flavor protease, papain, proteinase $\mathrm{K}$ and trypsin) on antioxidative activities of casein hydrolysate from goat milk were studied (Shu et al., 2015). The antioxidant activities of casein hydrolysates were assessed by evaluating hydrolysis degree, DPPH radical-scavenging activity, metal-chelating activity and superoxide radical scavenging activity. The results showed that the $\mathrm{Fe}^{2+}$-chelation activity, superoxide radical scavenging activity and the DPPH scavenging activities of casein hydrolysates by Alcalase was higher than the others. So the optimal proteinase for hydrolysis casein from goat milk to produce antioxidant peptide was Alcalase. Our laboratory screened and obtained the ACE inhibitory peptideproducing strain L. rhamnosus LR22 and the antioxidant peptide-producing strain $L$. plantarum L60 in the early stage of fermented goat milk (Chen et al., 2012). The effects of single protease (papain, Alcalase, flavor protease) and complex protease (Alcalase and papain, Alcalase and flavor protease, Alcalase, flavor protease and papain) on the two strains of goat milk separately fermented were studied (Chen et al., 2019). It is found that Alcalase has a significant effect on the production of ACE inhibitory peptides and antioxidant peptides by two strains of goat milk fermented separately. This article studies the influence for Alcalase on the preparation of ACE inhibitor peptides and antioxidant peptides by goat milk fermented by two strains.

School of Food and Biological Engineering, Shaanxi University of Science \& Technology.

Appropriate amounts of freeze-dried bacterial powder of $L$. plantarum L60 and L. rhamnosus LR22 were taken, aseptically placed in $121^{\circ} \mathrm{C}$ 
sterilized MRS broth, then incubated at $37^{\circ} \mathrm{C}$ for $24 \mathrm{~h}$ in an incubator to obtain a bacterial suspension of generation 1, and The 1st generation bacterial suspension was put into the MRS broth according to the $5 \%$ inoculum amount and the above steps were repeated twice to prepare the $3 \mathrm{rd}$ generation bacterial suspension, which was refrigerated. Reconstituted goat milk with a concentration of $12.5 \%$ dry matter was used, insert the $3^{\text {rd }}$ generation of the bacterial suspension, according to the inoculum amount of $5 \%$, then cultivated to curd at $37^{\circ} \mathrm{C}$; the procedure was twice repeated and the resulted product was kept in the refrigerator for further use.

\section{Protease-assisted probiotics fermentation process of goat milk}

Alcalase, L. plantarum L60 and L. rhamnosus LR22 were used as starter with Alcalase. Basic fermentation conditions were: enzyme addition $0.15 \%$, inoculation amount $5 \%$, fermentation time $12 \mathrm{~h}$, temperature $39^{\circ} \mathrm{C}$, bacterial ratio $1: 1$. The enzyme dosage was: $0.05 \%, 0.1 \%, 0.15 \%, 0.2 \%$, $0.25 \%$; inoculation amount was: $2 \%, 3 \%, 4 \%, 5 \%$, $6 \%$; fermentation time was: $8 \mathrm{~h}, 10 \mathrm{~h}, 12 \mathrm{~h}, 14 \mathrm{~h}, 16 \mathrm{~h}$; temperature was $35^{\circ} \mathrm{C}, 37^{\circ} \mathrm{C}, 39^{\circ} \mathrm{C}, 41^{\circ} \mathrm{C}, 43^{\circ} \mathrm{C}$; bacterial ratio was $3: 1,2: 1,1: 1,1: 2,1: 3$. To analyse the influence on peptide production, the indicators of $\mathrm{pH}$, titer acidity, DPPH free radical scavenging rate and ACE inhibition rate were considered.

\section{Assay of pH and acidity}

The $\mathrm{pH}$ was determined with a PHS-3C $\mathrm{pH}$ meter. (Shanghai Jingke Instrument Co., Ltd,Shanghai)

Sodium hydroxide titration method was used to determine the acidity value; the measuring unit used here was Toerner's degree $\left({ }^{\circ} \mathrm{T}\right)$. For the analysis, 10 $\mathrm{ml}$ of fermented milk sample were measured and poured into a $100 \mathrm{ml}$ conical flask, then $20 \mathrm{ml}$ of distilled water and 2-3 drops of alcohol phenolphthalein (indicator) were added. After mixing, titration was made with $0.1 \mathrm{~mol} / \mathrm{L}$ standard $\mathrm{NaOH}$ solution, with continuously shaking. The titration end point was considered when a reddish color was produced in the solution and remained unchanged within 30s. The milliliters (V) consumed from the $\mathrm{NaOH}$ standard solution were multiplied by 20 to get the titer acidity of $100 \mathrm{ml}$ fermented milk.

\section{Assay of DPPH free radical scavenging rate}

DPPH was dissolved in $95 \%$ ethanol and a DPPH radical solution with a concentration of $0.1 \mathrm{mmol} / \mathrm{L}$ was prepared. $2 \mathrm{~mL}$ of the whey sample were mixed with $8 \mathrm{~mL}$ of DPPH free radical solution as the experimental group. $2 \mathrm{~mL}$ from the ethanol solution were mixed with $8 \mathrm{~mL}$ DPPH radical solution as the control group. $2 \mathrm{~mL}$ of whey sample were mixed with $8 \mathrm{~mL}$ of ethanol solution as a blank group. Each group was placed in the dark for 30 minutes and then placed at $517 \mathrm{~nm}$ to measure the absorbance. The scavenging rate was calculated according to the following formula (Lu et al., 2016):

DPPH free radical scavenging rate $(\%)=$

$$
\left(1-\frac{A_{i}-A_{j}}{A_{0}}\right) \times 100
$$

In the formula (1) $A_{i}$ is the experimental group, $A_{j}$ is the blank group, and $A_{0}$ is the control group.

\section{Assay of ACE inhibitory activity of fermented goat milk by probiotics in vitro}

Borate buffer solution: slowly add $0.025 \mathrm{~mol} / \mathrm{L}$ borax solution to $0.1 \mathrm{~mol} / \mathrm{L}$ boric acid solution while stirring until the $\mathrm{pH}$ value of the buffer solution reaches 8.3.

Preparation of $0.1 \mathrm{UN} / \mathrm{mL}$ ACE solution: Dissolve ACE in the above-mentioned borate buffer solution to prepare a solution with a concentration of $0.1 \mathrm{UN} / \mathrm{mL}$.

Preparation of $5 \mathrm{mmol} / \mathrm{L}$ HHL solution: Dissolve HHL with a prepared borate buffer solution to prepare $5 \mathrm{mmol} / \mathrm{L}$.

As shown in Table 1, add each reagent to the test tube and preheat it in $37^{\circ} \mathrm{C}$ water bath for 5 minutes, then add ACE solution to start the reaction. After 30 minutes, the reaction is over and $1 \mathrm{~mol} / \mathrm{L} \mathrm{HCl}$ is added to stop the reaction. Then add $1.7 \mathrm{~mL}$ of ethyl acetate to each test tube and shake for 15 seconds. After layering, absorb $1 \mathrm{~mL}$ of the ethyl acetate layer into the test tube and put it in a $120^{\circ} \mathrm{C}$ oven.

Table 1. Measure methods for ACE inhibition rate

\begin{tabular}{|l|l|l|c|}
\hline \multirow{2}{*}{ Reagent } & \multicolumn{2}{l|}{ sample $/ \mu \mathrm{L}$} & $\mathrm{C}$ \\
\cline { 2 - 4 } & $\mathrm{A}$ & $\mathrm{B}$ & 250 \\
\hline HCl Solution & 0 & 0 & 200 \\
\hline HHLSolution & 200 & 200 & 0 \\
\hline ACE Inhibitor & 100 & 0 & $\begin{array}{l}\text { Preheat in } 37^{\circ} \mathrm{C} \text { water } \\
\text { bath for } 5 \mathrm{~min}\end{array}$ \\
\hline & 20 & 20 & $\begin{array}{l}\text { Preheat in } 37^{\circ} \mathrm{C} \text { water } \\
\text { bath for } 30 \mathrm{~min}\end{array}$ \\
\hline ACE & 250 & 250 & 0 \\
\hline & 0 & 100 & 100 \\
\hline HCl Solution & $\begin{array}{l}\text { Sodium borate } \\
\text { buffer }\end{array}$ & &
\end{tabular}


After it is evaporated to dryness, take it out and cool it. Finally add $3 \mathrm{~mL}$ of deionized to the test tube. After fully dissolved in water, measure the absorbance at a wavelength of $228 \mathrm{~nm}$, and calculate the ACE inhibition rate according to the following formula (2) (Shao, 2008):

ACE inhibition rate $(\%)=\frac{B-A}{B-C} \times 100$

\section{RESULTS AND DISCUSSION}

Effect of the main factors on fermentation of $L$. plantarum L60 and L. rhamnosus LR22

Taking the DPPH free radical scavenging rate, ACE inhibition rate, $\mathrm{pH}$ and acidity of fermented goat milk as indicators, the single factor experiment was used to investigate the enzyme addition, inoculum amount, fermentation time, temperature and bacterial ratio to compare the two bacterials of cofermented goat milk. The results are shown in Figures 1,2, 3, 4, and 5. The addition of alcalase can have a greater impact on the DPPH free radical scavenging rate (Figure 1a). With the increase for alcalase addition, scavenging rate for DPPH showed a trend of first increasing and then decreasing, reaching the maximum value of $70.6 \%$ when the enzyme dosage was $0.15 \%$. The ACE inhibition rate reached the maximum value of $83.4 \%$ when the enzyme dosage was $0.15 \%$. As the amount of enzyme increases, the DPPH free radical scavenging rate and $\mathrm{ACE}$ inhibition rate decrease, which may be due to excessive consumption of the substrate by the protease, which has a certain impact on the growth of the bacteria.

As Figure 1(b) shows, the enzyme addition has a small effect on $\mathrm{pH}$ and acidity. The maximum $\mathrm{pH}$ is 4.74 , the minimum is 4.63 , the maximum acidity is $100^{\circ} \mathrm{T}$ and the minimum is $97^{\circ} \mathrm{T}$. By comparing the effect of enzyme addition on several parameters of fermented goat milk technology, considering the optimal alcalase addition is $0.15 \%$.

Ahtesh (Ahtesh et al., 2016) used L. helveticus to ferment skimmed milk with a protease content of $0.14 \%$. After 12 hours of fermentation, the ACE inhibition rate reached $89.8 \%$. Chen (2006) used protease to assist the fermentation of lactic acid bacteria, and the added amount of protease was $0.032 \%$, which show that the specific enzyme addition should be determined according to different bacterials and different fermentation method.

Figure 2(a) shows that the inoculum size has little influence on the scavenging rate for DPPH free
In the formula (2) A means ACE inhibitor reacts with ACE and HHL at the same time; B means ACE reacts with $\mathrm{HHL}$; $\mathrm{C}$ means inactivated $\mathrm{ACE}$ reacts with HHL as the blank group.

radical. In inoculation amount is $5 \%$, the maximum value is $74.6 \%$. The amount of inoculation has a relatively large impact on the ACE inhibition rate. In the range of $3 \%-5 \%$, the ACE inhibition rate increased from $70.5 \%$ to $83.6 \%$ and then began to decline. As the inoculum size increases, the antioxidant activity and ACE inhibitory activity of fermented goat milk decrease instead. It may be that the protein in goat milk cannot meet the growth needs of so many bacterials, thereby increasing the secretion of bacteria. The hydrolysis of protease further hydrolyzes some biologically active peptides into smaller peptides; or it may be due to excessive acid production due to more live bacteria fermenting goat milk, thereby inhibiting the production of antioxidant peptides and ACE inhibitor peptides.

Figure 2(b) indicates that with the increase of the inoculum size, the $\mathrm{pH}$ keeps decreasing from 5.23 to 4.53 , and the keeps increasing, from $86^{\circ} \mathrm{T}$ to $102^{\circ} \mathrm{T}$.By comparing the influence of the inoculum amount on several parameters of the fermented goat milk process, considering the optimal inoculation amount is $5 \%$.

Figure 3 (a) shows that the changes of the scavenging rate for DPPH free radical rose rapidly from $42 \%$ to $73.6 \%$ with the fermentation time from $8 \mathrm{~h}$ to $12 \mathrm{~h}$. The ACE inhibition rate gradually increased with the progress of fermentation, reaching a maximum of $80.3 \%$ at $12 \mathrm{~h}$. After that the scavenging rate for DPPH free radical and ACE inhibition rate of fermented goat milk began to stabilize, which may be due to the growth of the bacteria reaching a stable period.

Figure 3 (b) shows that as the fermentation time increases, the $\mathrm{pH}$ keeps decreasing from 5.35 to 4.37, and the acidity keeps increasing, rising from $85^{\circ} \mathrm{T}$ to $103^{\circ} \mathrm{T}$. By comparing the influence of fermentation time on several parameters of fermented goat milk technology, comprehensive consideration to select $12 \mathrm{~h}$ as the optimal fermentation time. 

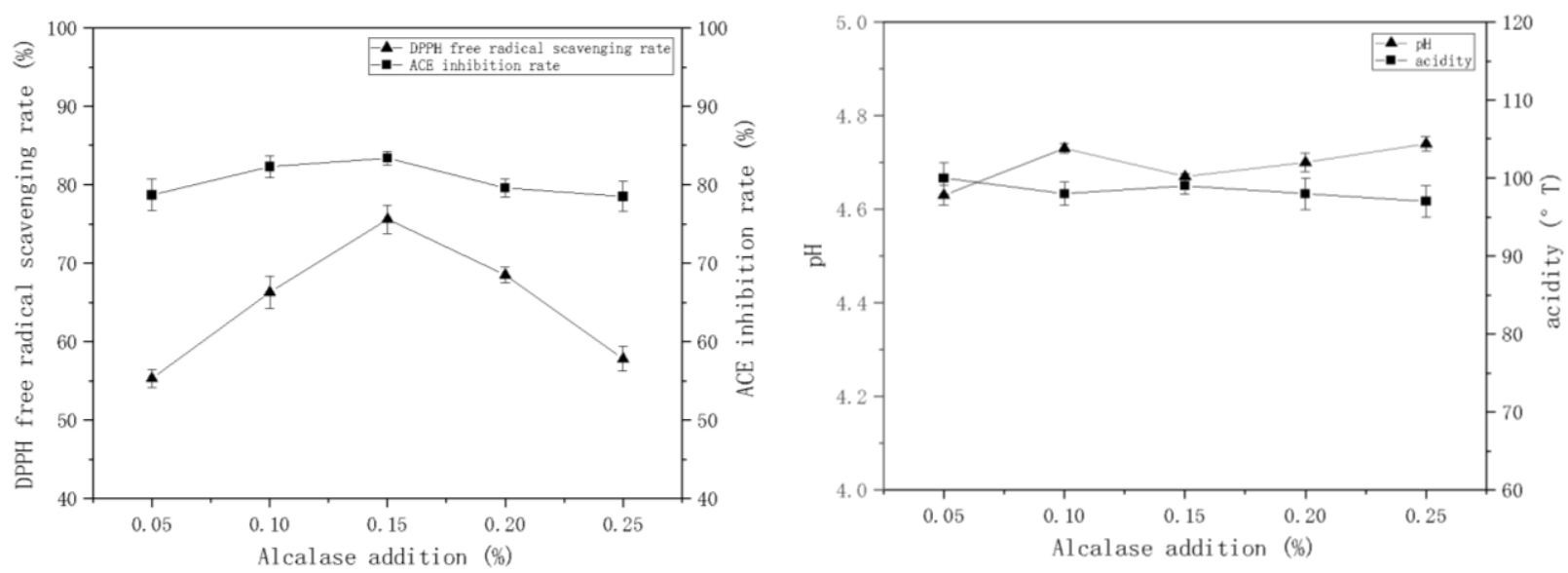

Figure 1. Effect of alcalase addition on DPPH free radical scavenging rate and ACE inhibition rate (a), $\mathrm{pH}$ and acidity (b) of goat milk fermented by L. plantarum L60 and L. rhamnosus LR22.
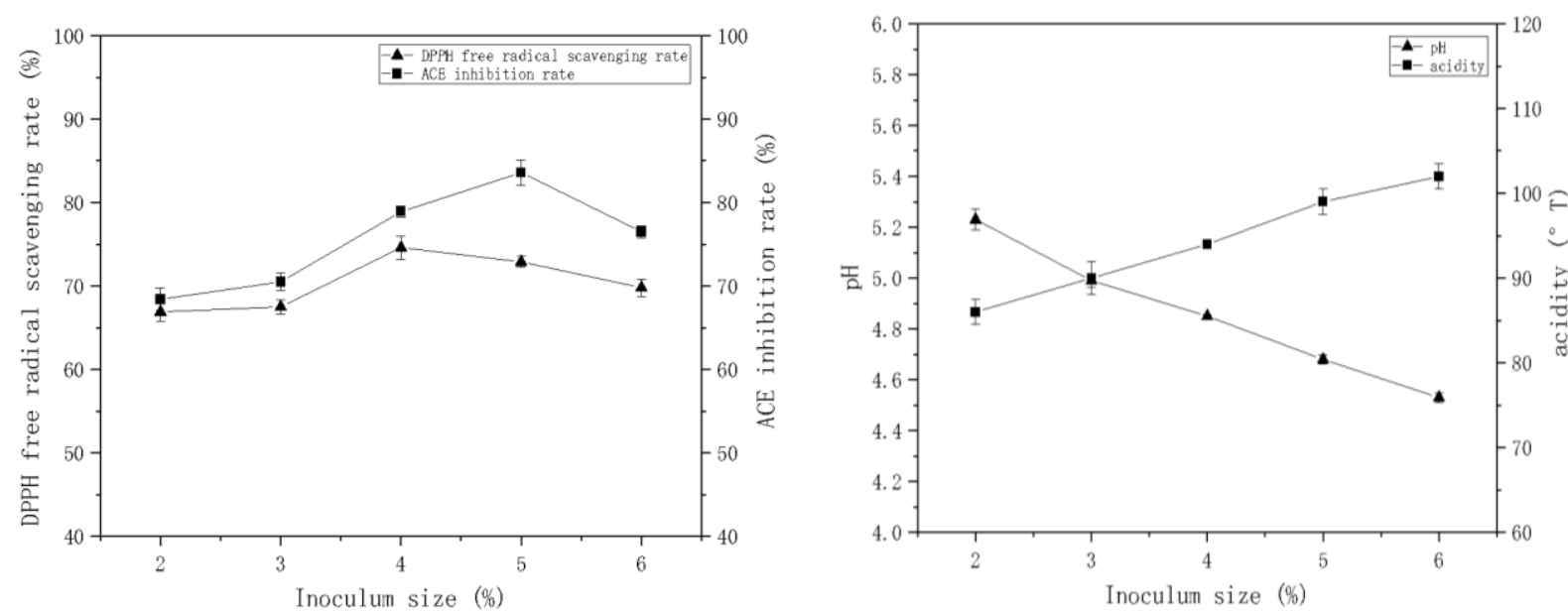

Figure 2. Effect of inoculum size on DPPH free radical scavenging rate and ACE inhibition rate (a), pH and acidity (b) of goat milk fermented by L. plantarum L60 and L. rhamnosus LR22
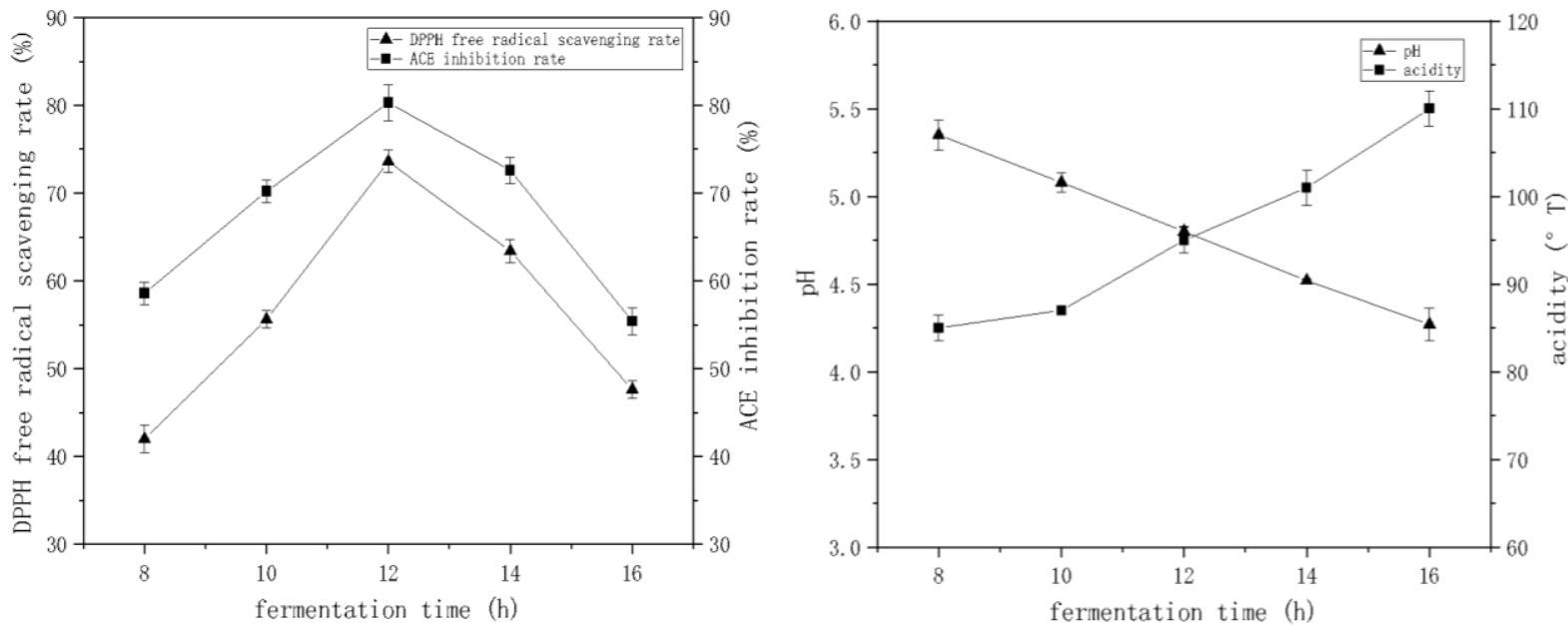

Figure 3. Effect of fermentation time on DPPH free radical scavenging rate and ACE inhibition rate (a), $\mathrm{pH}$ and acidity (b) of goat milk fermented by L. plantarum L60 and L. rhamnosus LR22

Figure 4(a) indicates that with the increase of fermentation temperature, the DPPH free radical scavenging rate shows a tendency of first increasing and then decreasing. The growth rate is faster in the range of $35-37^{\circ} \mathrm{C}$, and reaches the maximum value of $72.4 \%$ at $37^{\circ} \mathrm{C}$. Then it began to fall, and the 39 - 
41C leveled off. The ACE inhibition rate reached the maximum value of $80.9 \%$ at $37^{\circ} \mathrm{C}$, and then there was a downward trend. When it was greater than $39^{\circ} \mathrm{C}$, the ACE inhibition rate declined faster. When the temperature is low, the enzyme activity will be inhibited and the cell metabolism will slow down, resulting in slow growth of the bacteria; when the temperature is further increased to reach the suitable growth of the bacteria, the DPPH free radical scavenging rate and ACE inhibition rate of fermented goat milk will reach maximum; when the temperature is too high, it will also inhibit the activity of the protease, and even cause the death and inactivation of the bacteria, thereby reducing the antioxidant activity and ACE inhibitory activity of fermented goat milk.

Figure 4(b) indicates that the $\mathrm{pH}$ and acidity basically reach a constant state within the range of $37-39^{\circ} \mathrm{C}$, with both the $\mathrm{pH}$ being 4.85 and the acidity being $90-91^{\circ} \mathrm{T}$. By comparing the influence of temperature on several parameters of the fermented goat milk process, $37^{\circ} \mathrm{C}$ can be selected as the best fermentation temperature for follow-up experiments.

The mixed culture of bacterial may promote better growth of the two and have a better synergistic effect on the hydrolysis of protein, but the ratio of bacterial must be determined to achieve the best effect. Figure 5(a) shows that when the ratio of $L$. plantarum L60 to L. rhamnosus LR22 is 1:1, the scavenging rate for DPPH free radical reaches the maximum $70.2 \%$, and the ACE inhibition rate reaches the maximum $80.8 \%$.

As Figure 5(b) shows, the bacterial ratio has little effect on $\mathrm{pH}$ and acidity. The $\mathrm{pH}$ range is between $4.76-5$ and the acidity range is between $88-98^{\circ} \mathrm{T}$. By comparing the effects of bacterial ratio on several parameters of fermented goat milk technology, comprehensive considering that the optimal bacterial ratio of $L$. plantarum $L 60$ and $L$. rhamnosus LR22 is 1:1.
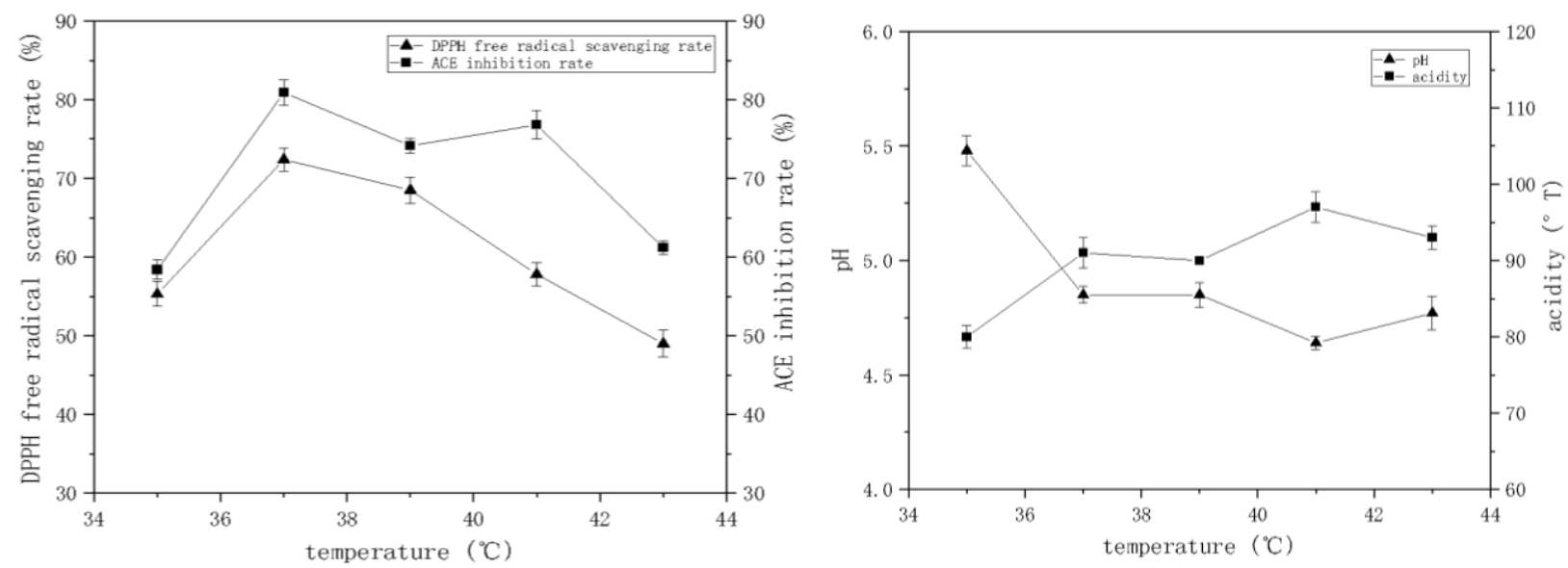

Figure 4. Effect of temperature on DPPH free radical scavenging rate and ACE inhibition rate(a), $\mathrm{pH}$ and acidity (b) of goat milk fermented by L. plantarum L60 and L. rhamnosus LR22
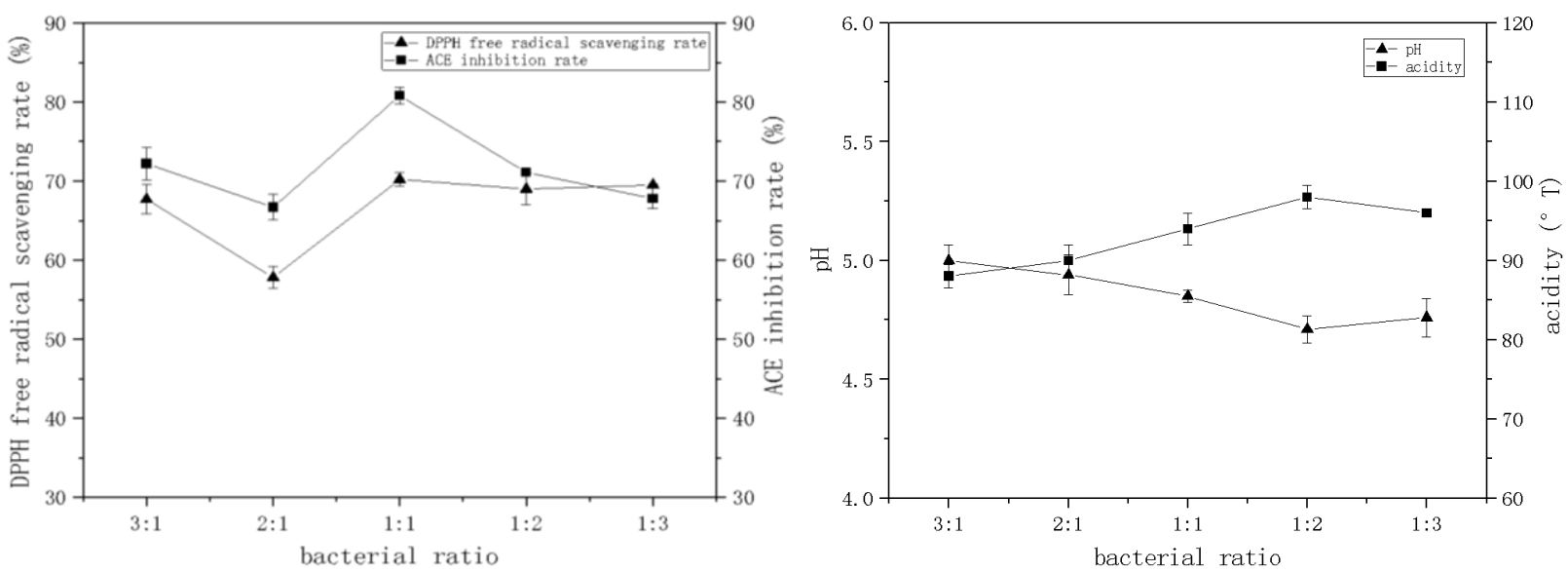

Figure 5. Effect of bacterial ratio on DPPH free radical scavenging rate and ACE inhibition rate(a), $\mathrm{pH}$ and acidity (b) of goat milk fermented by L. plantarum L60 and L. rhamnosus LR22 


\section{CONCLUSIONS}

The enzyme addition to different bacteria and under different fermentation methods has a significant effect on the antioxidant and ACE inhibitory activity of goat milk. The single factor tested here allowed to determine the optimal fermentation conditions as: alcalase addition $0.15 \%$, the inoculation amount $5 \%$, the bacterial ratio $L$. plantarum L60: L. rhamnosus LR22=1:1, fermentation time $12 \mathrm{~h}$ at $37^{\circ} \mathrm{C}$.

The DPPH free radical scavenging rate and ACE inhibition rate in probiotic goat milk reaches $74.6 \%$ and $83.6 \%$, which will help to further optimize the fermentation conditions of functional fermented goat milk products with high antioxidant and antihypertensive properties by response surface methodology to support for industrial production with reference in order to meet the needs of consumers.

\section{ACKNOWLEDGMENTS}

The work was partially supported by the National Key R\&D Program-Technology Boosts Economy 2020 Key Special Project, the Key Research and Development Program of Shaanxi (Program No. 2019ZDLNY06-02 and 2020NY-185), the Science and Technology Bureau of Yulin City (No. CXY-2020-088), the Science and Technology Bureau of Weiyang District (No. 201941).

\section{REFERENCES}

1. Ahtesh, F., Stojanovska, L. \& Shah, N., (2016). Effect of flavourzyme on angiotensin-converting enzyme inhibitory peptides formed in skim milk and whey protein concentrate during fermentation by Lactobacillus helveticus. Journal of Food Science, 81(1), 135-143. DOI:10.1111/1750-3841.13177

2. Chen, G.W. (2007). Physiological effects of protease-assisted lactic acid bacteria fermented milk whey on cardiovascular[D]. National Taiwan Ocean University

3. Chen, H., Ji, Z., Shu, G.W. (2012). Effect of probiotic Lactobacillus strains on Angiotensin I Converting Enzyme inhibitory activity from fermented goat milk. Advanced Materials Research, 531: 442-445. DOI: 10.4028/www.scientific.net/AMR.531.442

4. Chen, H., Yao, C.X. (2019). Effect of protease on antioxidant peptides produced by fermenting skimmed goat milk. Food Science And Technology, 44(9):16-20. DOI: 10.13684/j.cnki.spkj.2019.09.004

5. De, G.C., Espejo, F.J. \& Skibsted, L.H. (2014). Antioxidant peptides from goat milk protein fractions hydrolysed by two commercial proteases. International Dairy Journal, 39(1), 28-40. DOI: 10.1016/j.idairyj.2014.03.015

6. Elfahri K., Vasiljevic T. \& Yeager T. (2016). Anti-colon cancer and antioxidant activities of bovine skim milk fermented by selected Lactobacillus helveticus bacterials. Journal of Dairy Science, 99(1), 31-40. DOI:10.3168/jds.2015-10160

7. FitzGerald, R.J., Murray, B.A. \& Walsh, D. (2004). Hypotensive peptides from milk proteins. The Journal of nutrition, 134(4), 980-988.

8. Kris, E.P.M., Hecker, K.D. \& Bonanome, A. (2002). Bioactive compounds in foods: their role in the prevention of cardiovascular disease and cancer. The American Journal of Medicine, 113(9), 71-88. DOI:10.1016/S0002-9343(01)00995-0

9. Kudoh Y., Matsuda S. \& Igoshi K. (2001). Antioxidative peptide from milk fermented with Lactobacillus delbrueckii subsp. bulgaricus IFO13953. Nippon Shokuhin Kagaku Kogaku Kaishi, 48(1), 44-50.

10. I iang. X.I... Tan . K.Y. \& Su . H.Y. (2014). Research nrogress of milk-derived antioxidant active peptides. Journal of Food Safety and Quality, 5(09), 2776-2782. DOI: 10.19812/j.cnki.jfsq115956/ts.2014.09.031

11. Liang, M.Y. \& Chen, Q.S. (2009). Optimization of conditions for preparing ACE inhibitory peptides from fermented milk of Lactobacillus helveticus. Food Science, 30(21),155-160.

12. Lu, H.H., Pan, D.D. \& Lu, L.S. (2010). Optimization of the conditions for preparing ACE inhibitory peptides by fermenting whey protein from Lactobacillus helveticus. Food Science, 31(03), 165-169.

13. Lu, J.X., Ya, Y.H. \& Hong, Y.H. (2016). Purification and identification of antioxidative peptides from dry-cured Xuanwei ham. Food Chemistry, 194, 951-958. DOI: 10.1016/j.foodchem.2015.08.101

14. L S, T. \& J, T P. (2003). A fermented milk high in bioactive peptides has a blood pressure-lowering effect 
in hypertensive subjects. 77(2), 326-300

15. Meena, K., Kapila, S. \& Chand, R. (2008). Immunomodulatory effect of oral administration of milk fermented with Lactobacillus helveticus in mice. Milchwissenschaft, 63(1), 27-29.

16. Nakamura, Y., Yamamoto, N. \& Saksi, K. (1995). Purification and characterization of angiotensin Iconverting enzyme inhibitors from sour milk. Joumal of Dairy Science, 78(4), 777-783. DOI:10.3168/jds.S0022-0302(95)76689-9

17. Ribeiro, M.C.E., Chaves, K.S. \& Gebara, C. (2014). Effect of microencapsulation of Lactobacillus acidophilus LA-5 on physicochemical, sensory and microbiological characteristics of stirred probiotic yoghurt. Food Research International, 66, 424-431. DOI: 10.1016/j.foodres.2014.10.019

18. Soares, J.K.B., Melo, A.P.R.d. \& Medeiros, M.C. (2013). Anxiety behavior is reduced, and physical growth is improved in the progeny of rat dams that consumed lipids from goat milk: An elevated plus maze analysis. Neuroscience Letters, 552, 25-29. DOI: 10.1016/j.neulet.2013.07.028

19. Shan, J., Yan, Z.W. \& Zheng, S.F. (2019). Optimization of fermentation conditions for probiotic starter suitable for skimmed goat milk. China Brewing, 38(04), 136-140.

20. Shao, H. (2008). Screening of blood pressure-lowering probiotics and their fermentation characteristics[D]. Yangzhou University

21. Shu, G.W., Zhang, Q., Chen, H., Wan, H.C., Li, H., (2015). Effect of five proteases including alcalase, flavourzyme, papain, proteinase $\mathrm{k}$ and trypsin on antioxidative activities of casein hydrolysate from goat milk. Acta Universitatis Cibiniensis, 19, 65-74. DOI: 10.1515/aucft-2015-0015

22. Soleymanzadeh N., Mirdamadi S. \& Kianirad M. (2016). Antioxidant activity of camel and bovine milk fermented by lactic acid bacteria isolated from traditional fermented camel milk. Dairy Science \&Technology, 96, 443-457. DOI:10.1007/s13594-016-0278-1

23. Tovar, P.E.G., Guerrero, B.L. \& Lugo, C.E.J.C.J.o.F. (2017). Antioxidant activity of hydrolysates and peptide fractions of glutelin from cocoa (Theobroma cacao L.) seed. Cyta Journal of Food, 15, 489-496. DOI:10.1080/19476337.2017.1297963

24. Van der Ven, C., Gruppen, H. \& de Bont, D.B. (2002). Optimisation of the angiotensin converting enzyme inhibition by whey protein hydrolysates using response surface methodology. International Dairy Journal, 12(10), 813-820. DOI:10.1016/S0958-6946(02)00077-8

25. Xu, M.H., Wei, L. \& Dai, Z. (2015). Effects of goat milk-based formula on development in weaned rats. Food Nutrition Research, 59(1), 28610. DOI:10.3402/fnr.v59.28610 